\title{
Anaerobic Mono-digestion of Turkey Manure: Efficient Revaluation to Obtain Methane and Soil Conditioner
}

\author{
Rolando Chamy, Elba Vivanco, Carlos Ramos \\ School of Biochemical Engineering, Pontificia Universidad Católica de Valparaíso, Valparaíso, Chile \\ E-mail: rchamy@ucv.cl \\ Received May 5, 2011; revised June 8, 2011; accepted July 13, 2011
}

\begin{abstract}
This work demonstrates the possibility to make a full valuation of a solid waste such as turkey manure, to obtain methane and a soil conditioner/fertilizer from turkey manure anaerobic digestion in a mesophilic pilot-scale continuous stirred tank reactor at different organic loading rates (OLR) (from 0.5 to $2.5 \mathrm{kgVS} / \mathrm{m}^{3} \mathrm{~d}$ ). The application of the anaerobic mono-digestion for the turkey manure treatment was an efficient alternative, because high volatile solids removal and methane were obtained in addition to obtaining a stabilized solid waste that can be applied as soil conditioner, based on its nutritional parameters and humic substances content. In this way, the turkey manure anaerobic digestion can be applied avoiding the co-digestion of the manure with other wastes and allows a process devoid of pollutant emissions, obtaining two products. The reactor operation depends on the OLR, and its operation does not allow an OLR above $1.5 \mathrm{kgVS} / \mathrm{m}^{3} \mathrm{~d}$. Higher OLR produced a decrease in the TS and VS removals and methane productivity.
\end{abstract}

Keywords: Methane, Biomethanization, Solid Wastes, Turkey Manure, Soil Conditioner, Fertilizer

\section{Introduction}

The anaerobic digestion is a biological process, involving different kinds of microorganisms, which is accomplished by four sequential steps (hydrolysis, acidogenesis, acetogenesis and methanogenesis). In this manner, organic matter is transformed into biogas, mainly made up by methane, $60 \%-70 \%$ of the biogas. Due to environmental, energy, economic and legal considerations, the anaerobic digestion for solid waste treatment is a process that, in most of the cases, is the best way to transform the organic matter into value-added products, like methane and a stabilized sludge with soil conditioner characteristics, avoiding the disposal of the solid waste in a dump or landfill, incineration and composting [1,2]. However, the solid waste anaerobic digestion is a complex process, from a kinetic and process point of view, due to the high solid content, low moisture and waste composition, which makes the hydrolytic phase to be the limiting step. For the solid wastes biomethanization, the continuous stirred tank reactor (CSTR) is the main industrial-scale reactor type used, due to the simplicity of the process, the reactor operation and the lower investment cost [3]. An important operation parameter is the organic loading rate (OLR), because it affects the hydraulic retention time (HRT). Maintaining the reaction volume, an increase on the OLR, produces a decrease in HTR, so the reaction time must be proper to convert the waste to methane.

The possibility to generate a process without pollutant emissions and obtaining value added products are part of the current focus of environmental biotechnology. In this sense, anaerobic digestion achieves these objectives, due to the possibility to convert waste (low-cost raw material) into biofuels (hydrogen and/or methane) and an effluent (stabilized waste) can be used as fertilizer or soil conditioner. Therefore, the waste is completely up-valued in its energy and fertilizer potentials, which today in Chile is not totally exploited.

Until now, the literature reports the application of anaerobic digestion only to obtain methane and doesn't show how the operational parameters of the reactor affect the production of biogas and a soil conditioner/fertilizer. Also, according to the literature, the anaerobic manure mono-digestion cannot be achieved, the co-digestion of manure with other wastes being the only viable process.

This work demonstrates the possibility to completely up-valuate the raw turkey manure, without its co-digestion, to obtain methane and a soil conditioner/fertilizer from the turkey manure anaerobic mono-digestion in a 
pilot-scale continuous stirred tank reactor, evaluating the operation of the CSTR at different organic loading rates.

\section{Materials and Methods}

\subsection{Inoculum}

Anaerobic sludge from an industrial-scale CSTR for the treatment of sludge from a sewage wastewater plant (activated sludge system) was used as inoculum. The main characteristics of the inoculum are show in Table $\mathbf{1}$, which was characterized by low concentration of ammonium and acetic acid. The methanogenic activity of the sludge was 0.14 [gCOD $\left.\mathrm{gH}_{4} / \mathrm{gVSSd}\right]$.

\subsection{Waste Characteristics}

The waste used was raw turkey manure, provided by a turkey breeding, and composed, mainly, by manure, chips and feathers. Chips were part of the layer on which the turkeys are confined. The manure was collected, approximately once a month; and it was stored in a refrigeration chamber $\left(4^{\circ} \mathrm{C}\right)$ to avoid changes on its initial composition. Table 2 shows manure composition, which has high solid concentration $(51.2 \%(\mathrm{w} / \mathrm{w}))$, of which $71.5 \%$ was organic matter, expressed as volatile solids. Also, high ammonium concentration was found. The chemical oxygen demand (COD) was $1.1 \mathrm{gO}_{2} / \mathrm{gTS}$.

\subsection{Reactor}

The study was made in a pilot-scale CSTR with $2.0 \mathrm{~m}^{3}$ of total volume $\left(1.6 \mathrm{~m}^{3}\right.$ active volume). The experimental pilot scale set-up consisted on a fiberglass reactor $(6.0$ $\mathrm{mm}$ thickness) and a circular steel lid ( $8.0 \mathrm{~mm}$ thickness). The heating was automatically fixed at $37^{\circ} \mathrm{C}$. The mixing was maintained at $85 \mathrm{rpm}$ through a gear motor (1 HP power) and the system consisted on a stainless steel central axis with 4 inclined blades $\left(45^{\circ}\right)$ and 4 fiberglass baffles. The digester is located in Quillota (V region,

Table 1. Inoculum characteristics.

\begin{tabular}{lllllllll}
\hline \multirow{2}{*}{$\begin{array}{l}\mathrm{COD} \\
{\left[\mathrm{gO}_{2} / \mathrm{gTS}\right]}\end{array}$} & \multicolumn{2}{l}{ Volatile fatty acids $[\mathrm{mg} / \mathrm{L}]$} & \begin{tabular}{l}
$\mathrm{VSS}$ \\
\cline { 3 - 6 }
\end{tabular} & $\begin{array}{l}\text { acetic } \\
{[\mathrm{g} / \mathrm{L}]}\end{array}$ & $\begin{array}{l}\mathrm{TS} \\
{[\mathrm{g} / \mathrm{L}]}\end{array}$ & $\begin{array}{l}\mathrm{VS} \\
{[\mathrm{g} / \mathrm{L}]}\end{array}$ & $\begin{array}{l}\mathrm{NH}_{4}^{+} \\
{[\mathrm{g} / \mathrm{L}]}\end{array}$ \\
\hline 0.9 & 116.9 & 39.2 & 0.0 & 18.4 & 29.9 & 18.5 & 0.5 \\
\hline
\end{tabular}

Table 2. Turkey manure characteristics.

\begin{tabular}{cccccc}
\hline $\begin{array}{l}\text { Density } \\
{\left[\mathrm{kg} / \mathrm{m}^{3}\right]}\end{array}$ & $\begin{array}{c}\text { TS [\%w/w] } \\
\text { (wet basis) }\end{array}$ & $\begin{array}{c}\text { VS [\%w/w] } \\
\text { (dry basis) }\end{array}$ & $\begin{array}{c}\text { Moisture } \\
{[\%]}\end{array}$ & $\begin{array}{c}\mathrm{COD} \\
{\left[\mathrm{gO}_{2} / \mathrm{gTS}\right]}\end{array}$ & $\begin{array}{c}\mathrm{NH}_{4}^{+} \\
{[\mathrm{g} / \mathrm{L}]}\end{array}$ \\
\hline $424.0 \pm 4.3$ & $51.2 \pm 9.8$ & $71.5 \pm 20.3$ & $48.8 \pm 8.8$ & $1.1 \pm 0.2$ & $2.2 \pm 0.3$ \\
\hline
\end{tabular}

Chile), at the School of Agronomy of Pontificia Universidad Católica de Valparaíso. Figure 1 shows the reactor scheme.

\subsection{Experimental Procedure}

The reactor was inoculated with anaerobic sludge, filling the digester up to the reaction volume $\left(1.6 \mathrm{~m}^{3}\right)$. Then, the reactor was airtight closed and the mixing was started. Later, nitrogen gas was injected to remove the oxygen inside the reactor. Once the reactor was loaded with sludge, the heating system was activated (programmed to $37^{\circ} \mathrm{C}$ ). The reactor feeding was semi-continuous, i.e., fresh waste was added once per day to the reactor. Five organic loading rates were analysed (see Table 3). An increase in the OLR produced a decrease in the HRT. During the reactor operation, total solids (TS), volatile solids (VS), ammonium ( $\mathrm{NH}_{4}^{+}$) concentrations, and biogas production and composition were determined periodically. At different OLR, the generated effluent (solid fraction, obtained by solar drying, and liquid fraction, obtained by filtration) was evaluated as fertilizer and soil conditioner, by means of determination of macro and micronutrients and humic content. The length of each organic loading rate depended on the stability of the reactor behaviour.

\subsection{Analytical Methodology}

The TS and VS concentrations were measured according to Standard Methods [4] and the $\mathrm{NH}_{4}^{+}$concentration was quantified by the utilization of a selective electrode
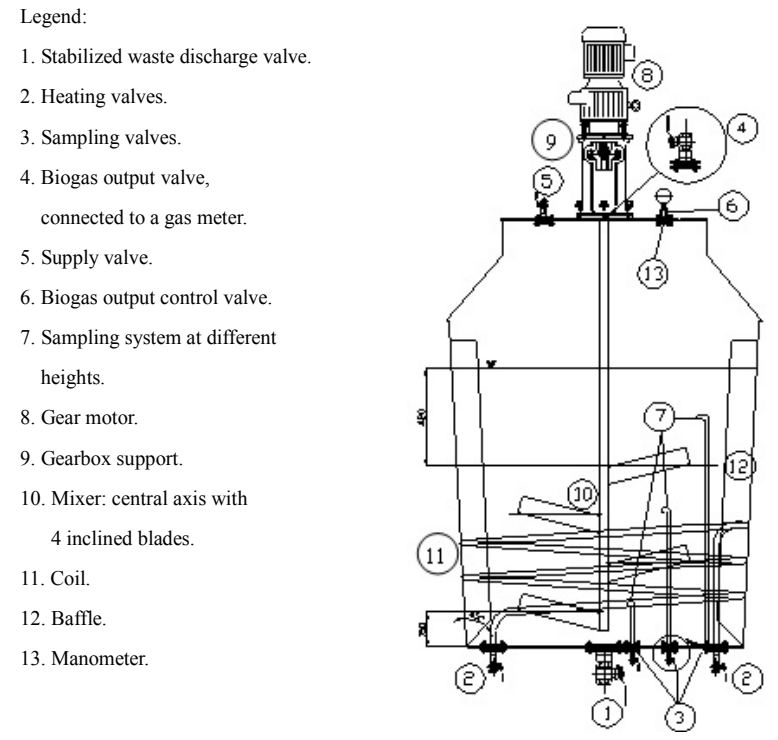

Figure 1. Overall scheme of the pilot-scale reactor, indicating the valve arrangement and the mixer system, heating and sampling. 
Table 3. Average values of the operational parameters during each OLR studied for the pilot-scale CSTR operation in the anaerobic treatment of turkey manure.

\begin{tabular}{|c|c|c|c|c|c|c|}
\hline \multirow{2}{*}{$\begin{array}{c}\text { Operation } \\
\text { Time [d] }\end{array}$} & \multirow{2}{*}{$\begin{array}{c}\text { OLR } \\
{[\mathrm{kgVS} /} \\
\left.\mathrm{m}^{3} \mathrm{~d}\right]\end{array}$} & \multirow{2}{*}{$\begin{array}{l}\text { HRT } \\
{[\mathrm{d}]}\end{array}$} & \multicolumn{2}{|c|}{$\begin{array}{c}\text { Removal } \\
{[\%]}\end{array}$} & \multirow{2}{*}{$\begin{array}{c}\mathrm{CH}_{4} \text { content } \\
{[\%]}\end{array}$} & \multirow{2}{*}{$\begin{array}{c}\text { Methane } \\
\text { productivity } \\
{\left[\mathrm{m}^{3} \mathrm{CH}_{4} / \mathrm{m}^{3}{ }_{\mathrm{R}} \mathrm{d}\right]}\end{array}$} \\
\hline & & & $T S$ & VS & & \\
\hline $1-121$ & 0.5 & 192 & 88.3 & 91.5 & 70.0 & 0.21 \\
\hline $122-191$ & 1.0 & 160 & 83.6 & 87.6 & 70.0 & 0.52 \\
\hline $192-280$ & 1.5 & 77 & 72.0 & 78.1 & 60.0 & 0.50 \\
\hline $281-315$ & 2.0 & 55 & 62.6 & 67.7 & 22.0 & 0.19 \\
\hline $316-337$ & 2.5 & 43 & 60.1 & 66.1 & 25.0 & 0.24 \\
\hline
\end{tabular}

(Cole-Parmer, model: 27502-03). The methane and carbon dioxide content were analysed with gas chromatography: PerkinElmer chromatograph (Clarus 500 model, packed column, thermal conductivity detector). The methane and biogas volume were expressed in standard pressure and temperature conditions $\left(1 \mathrm{~atm}\right.$ and $\left.0^{\circ} \mathrm{C}\right)$. Macro and micronutrients were determined according to [5] and the humic and fulvic content was analyzed through [6]. The methanogenic activity was measurement according to [7].

\section{Results and Discussion}

\subsection{Solids Removal}

Figure 2 shows the CSTR behaviour at the different OLR studied, with respect to the total and volatile solids removal. Table 3 presents the data obtained. An increase in the organic loading rate produced a gradual decrease in the TS and VS removals, which had the same trends. During the start-up (OLR of $0.5 \mathrm{kgVS} / \mathrm{m}^{3} \mathrm{~d}$ ), first fluctuation occurred and later stabilization occurred. For the second OLR $\left(1.0 \mathrm{kgVS} / \mathrm{m}^{3} \mathrm{~d}\right)$, the TS and VS removals maintained relatively constant, with an average removal of over $80 \%$ for TS and $90 \%$ for VS. When the CSTR was operated from an organic loading rate of 1.5 up to $2.5 \mathrm{kgVS} / \mathrm{m}^{3} \mathrm{~d}$, the total and volatile solids removals decreased gradually with an increase in the OLR. The minimal VS removal was $66 \%$ (for the OLR of 2.5 $\mathrm{kgVS} / \mathrm{m}^{3} \mathrm{~d}$ ), which was higher than reported for manure in pilot and industrial-scale CSTR $(50 \%-58 \%$ of VS removal) [8-10]. The process could be negatively affected in terms of the low hydraulic retention time, which could not allow the proper metabolism/degradation of the recalcitrant substances, thus avoiding to obtain higher removal. Another fact could be the solids and ammonium concentrations inside the reactor. During the organic loading rates of 0.5 and $1.0 \mathrm{kgVS} / \mathrm{m}^{3} \mathrm{~d}$, the TS and $\mathrm{NH}_{4}{ }^{+}$ maintained under 40.0 and $4.0 \mathrm{~g} / \mathrm{L}$ for total solid and am-

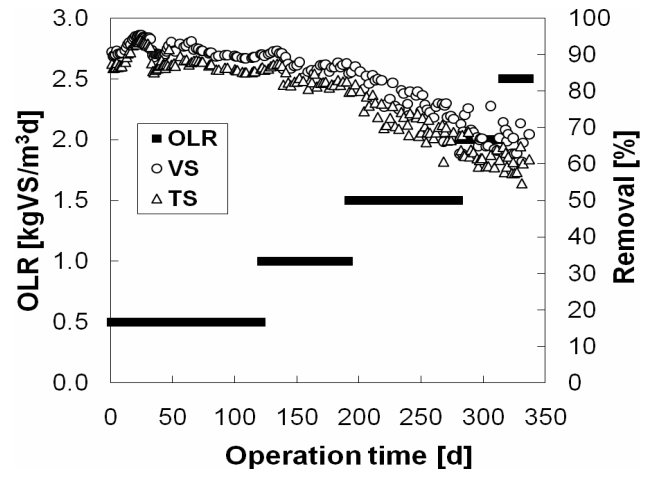

Figure 2. TS and VS removals during the operation of the pilot-scale CSTR at different OLR for the anaerobic treatment of turkey manure.

monium, respectively (data not shown). This TS concentration inside the reactor is appropriate for the anaerobic digestion of solid wastes, because the reported suitable range is between 10 and $50 \mathrm{~g} / \mathrm{L}$ of TS [11-13]. The reported inhibitory ammonium concentration for methanogenic bacteria is between 3.5 and $18.3 \mathrm{~g} / \mathrm{L}[12,14-$ 21]. With an increase on the organic loading rate (from 1.5 to $2.5 \mathrm{kgVS} / \mathrm{m}^{3} \mathrm{~d}$ ) the total solids and ammonium concentrations increased gradually, over 50.0 and $5.0 \mathrm{~g} / \mathrm{L}$ respectively, exceeding the recommended concentrations for biomethanization which could negatively affect the reactor behaviour. Detailed information of the reactor operation can be obtained in [13].

\subsection{Methane and Biogas Production}

In relation to methane production, Figure 3 shows methane productivity obtained with all the OLRs studied. Table 3 shows the values obtained. In the early stage of operation, the reactor presented a high fluctuation on methane production, which can be associated to the biomass acclimatization to the waste. Later, with an increase

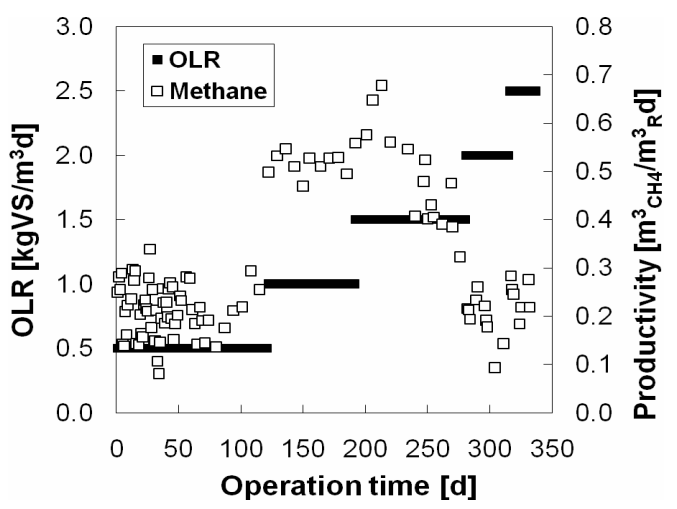

Figure 3. Methane productivity during the operation of the pilot-scale CSTR at different OLRs for turkey manure anaerobic treatment. 
in the OLR, the methane productivity had an increase, presenting high stability when the organic loading rate was $1.0 \mathrm{kgVS} / \mathrm{m}^{3} \mathrm{~d}$, compared to higher studied OLR. According to the results, an OLR above $1.5 \mathrm{kgVS} / \mathrm{m}^{3} \mathrm{~d}$ produced a decrease on the methane productivity.

During the reactor operation, the methane content decreased gradually with an increase in the OLR (see Table 3). The biogas composition varied from 70 up to 20 $\%$ of methane, between an OLR of 0.5 to $2.5 \mathrm{kgVS} / \mathrm{m}^{3} \mathrm{~d}$. The rest of the biogas content was carbon dioxide, which was to be expected. For this reason, the methane production decreased when the organic loading rate increased; which can be expected, because the HRT decreased and/or the $\mathrm{NH}_{4}{ }^{+}$or TS increased to inhibitory concentrations. According to these results, the maximum methane productivity was $0.52 \mathrm{~m}^{3}{ }_{\mathrm{CH}} / \mathrm{m}^{3}{ }_{\mathrm{R}} \mathrm{d}$ with the OLR of 1.0 $\mathrm{kgVS} / \mathrm{m}^{3} \mathrm{~d}$. However, when the OLR was $1.5 \mathrm{kgVS} / \mathrm{m}^{3} \mathrm{~d}$, the methane productivity was slightly lower than with $1.0 \mathrm{kgVS} / \mathrm{m}^{3} \mathrm{~d}\left(0.50 \mathrm{~m}^{3} \mathrm{CH}_{4} / \mathrm{m}^{3}{ }_{\mathrm{R}} \mathrm{d}\right)$, which would indicate that when the OLR is $1.5 \mathrm{kgVS} / \mathrm{m}^{3} \mathrm{~d}$, it is possible to have a higher organic matter treatment obtaining an appropriate methane production. The manure biomethanization in mesophilic CSTR is reported with a methane productivity of $0.3-1.0 \mathrm{~m}^{3}{ }_{\mathrm{CH} 4} / \mathrm{m}_{\mathrm{R}}^{3} \mathrm{~d}$ for an OLR of 1.1 $\left.3.3 \mathrm{kgVS} / \mathrm{m}^{3} \mathrm{~d}[10,22-27]\right)$. According to what has been already published, for the results obtained, with a low OLR $\left(1.5 \mathrm{kgVS} / \mathrm{m}^{3} \mathrm{~d}\right)$, an appropriate methane productivity $\left(0.50 \mathrm{~m}^{3} \mathrm{CH}_{4} / \mathrm{m}^{3}{ }_{\mathrm{R}} \mathrm{d}\right)$ was obtained. This could be due to the high VS removal obtained (67.7\%), compared with the reported values, allowing to convert the organic waste into methane.

\subsection{Stabilized Waste as Soil Conditioner}

At organic load rates of 1.0 and $2.0 \mathrm{kgVS} / \mathrm{m}^{3} \mathrm{~d}$ (between $120-130$ and $305-315$ days the reactor operation), the composition of macro and micronutrients in the effluent of the digester was determined (see Tables 4 and 5), analysing the solid fraction of the effluent (dry sludge through solar drying) and the entire effluent (sludge without pre-treatment). For the dry sludge (see Table 4), an increase in the OLR produced an increase in electrical conductivity, organic matter, available nitrogen, copper and boron, exchangeable magnesium and $\mathrm{C} / \mathrm{N}$ ratio; however, the $\mathrm{pH}$, exchangeable potassium, sodium and calcium and the available phosphorus, zinc, manganese and iron decreased. The appropriate values of the solid fraction of the effluent would allow the re-use of the liquid fraction in the process, with the purpose of maintaining an appropriate TS concentration inside the reactor. With respect to the entire effluent (without pre-treatment) (see Table 5), all the quantified parameters, except $\mathrm{pH}$, highly increased with an increase in the OLR; which can
Table 4. Macro and micronutrient in solid fraction (dry sludge through solar drying) of the effluent of the pilot-scale CSTR operation in the turkey manure anaerobic treatment.

\begin{tabular}{|c|c|c|c|c|c|}
\hline \multirow{2}{*}{ Parameter } & \multirow{2}{*}{ Unit } & \multicolumn{2}{|c|}{ OLR $\left[\mathrm{kgVS} / \mathrm{m}^{3} \mathrm{~d}\right]$} & \multicolumn{2}{|c|}{$\%^{1}$} \\
\hline & & 1.0 & 2.0 & Decrease & Increase \\
\hline $\mathrm{pH}$ & & 7.2 & 6.55 & 9.0 & \\
\hline $\begin{array}{c}\text { Electrical } \\
\text { conductivity }\end{array}$ & {$[\mathrm{dS} / \mathrm{m}]$} & 7.94 & 13.5 & & 70.0 \\
\hline Organic matter & {$[\%]$} & 59.2 & 88.8 & & 50.0 \\
\hline $\begin{array}{c}\text { Available } \\
\text { nitrogen }\end{array}$ & {$[\mathrm{mg} / \mathrm{kg}]$} & 2556 & 2746 & & 7.4 \\
\hline $\begin{array}{l}\text { Available } \\
\text { phosphorus }\end{array}$ & {$[\mathrm{mg} / \mathrm{kg}]$} & 4044 & 1710 & 57.7 & \\
\hline $\begin{array}{l}\text { Available } \\
\text { potassium }\end{array}$ & {$[\mathrm{mg} / \mathrm{kg}]$} & 25856 & 21004 & 18.8 & \\
\hline $\begin{array}{c}\text { Exchangeable } \\
\text { potassium }\end{array}$ & {$\left[\mathrm{cmol}^{+} / \mathrm{kg}\right]$} & 66.1 & 53.7 & 18.8 & \\
\hline $\begin{array}{l}\text { Exchangeable } \\
\text { sodium }\end{array}$ & {$\left[\mathrm{cmol}^{+} / \mathrm{kg}\right]$} & 24.1 & 11.6 & 51.9 & \\
\hline $\begin{array}{l}\text { Available } \\
\text { copper }\end{array}$ & {$[\mathrm{mg} / \mathrm{kg}]$} & 63.5 & 83.4 & & 31.3 \\
\hline $\begin{array}{l}\text { Available } \\
\text { zinc }\end{array}$ & {$[\mathrm{mg} / \mathrm{kg}]$} & 399 & 102 & 74.4 & \\
\hline $\begin{array}{c}\text { Available } \\
\text { boron }\end{array}$ & {$[\mathrm{mg} / \mathrm{kg}]$} & 1.36 & 43.3 & & 3083.8 \\
\hline $\begin{array}{l}\text { Available } \\
\text { manganese }\end{array}$ & {$[\mathrm{mg} / \mathrm{kg}]$} & 63.4 & 28.1 & 55.7 & \\
\hline Available iron & {$[\mathrm{mg} / \mathrm{kg}]$} & 482 & 196 & 59.3 & \\
\hline $\begin{array}{l}\text { Exchangeable } \\
\text { Magnesium }\end{array}$ & {$\left[\mathrm{cmol}^{+} / \mathrm{kg}\right]$} & 4.14 & 7.47 & & 80.4 \\
\hline $\mathrm{C} / \mathrm{N}$ ratio & & 10.7 & 22.8 & & 113.1 \\
\hline $\begin{array}{l}\text { Exchangeable } \\
\text { calcium }\end{array}$ & {$\left[\mathrm{cmol}^{+} / \mathrm{kg}\right]$} & 12 & 8.95 & 25.4 & \\
\hline
\end{tabular}

${ }^{1}$ based on the OLR of $1.0 \mathrm{kgVS} / \mathrm{m}^{3} \mathrm{~d}$.

be excessive or toxic for the nutritional requirements of the plants and/or for physical-chemical properties of the soil. Therefore, the organic load rate had an effect on the nutritional composition of the effluent. These results show that the solid fraction of the stabilized turkey manure through anaerobic digestion can be applied as a fertilizer or have the characteristic to be an A class sludge (unrestricted agricultural use for health reasons), and can be used in the agricultural, forest and gardening sectors; avoiding by in this manner its disposal on dumps. Another parameter required to know about the potential of the application of the stabilized waste to soil conditioner is the content of humic and fulvic acids, which results are shown in Table 6. The entire effluent presents higher concentrations of humic and fulvic acids than the liquid fraction (filtrate of the entire effluent) of the effluent. 
Table 5. Macro and micronutrient in the entire effluent (sludge without pre-treatment) of the effluent of the pilotscale CSTR operation in the turkey manure anaerobic treatment.

\begin{tabular}{|c|c|c|c|c|c|}
\hline \multirow{2}{*}{ Parameter } & \multirow{2}{*}{ Unit } & \multicolumn{2}{|c|}{ OLR $\left[\mathrm{kgVS} / \mathrm{m}^{3} \mathrm{~d}\right]$} & \multicolumn{2}{|c|}{$\%^{1}$} \\
\hline & & 1.0 & 2.0 & Decrease & Increase \\
\hline $\mathrm{pH}$ & & 8.16 & 7.84 & 3.9 & \\
\hline $\begin{array}{l}\text { Electrical } \\
\text { conductivity }\end{array}$ & {$[\mathrm{ds} / \mathrm{m}]$} & 18.2 & 36.5 & & 100.5 \\
\hline Nitrate & {$[\mathrm{mg} / \mathrm{L}]$} & 125 & 594 & & 375.2 \\
\hline Phosphate & {$[\mathrm{mg} / \mathrm{L}]$} & 2296 & 16246 & & 607.6 \\
\hline Bicarbonate & {$[\mathrm{mg} / \mathrm{L}]$} & 12678 & 35569 & & 180.6 \\
\hline Sulphate & {$[\mathrm{mg} / \mathrm{L}]$} & 489 & 5430 & & 1010.4 \\
\hline Chloride & {$[\mathrm{mg} / \mathrm{L}]$} & 1001 & 2723 & & 172.0 \\
\hline Ammonium & {$[\mathrm{mg} / \mathrm{L}]$} & 2967 & 8483 & & 185.9 \\
\hline Calcium & {$[\mathrm{mg} / \mathrm{L}]$} & 36.1 & 2579 & & 7044.0 \\
\hline Magnesium & {$[\mathrm{mg} / \mathrm{L}]$} & 0.92 & 648 & & 70334.8 \\
\hline Potassium & {$[\mathrm{mg} / \mathrm{L}]$} & 941 & 4143 & & 340.3 \\
\hline Sodium & {$[\mathrm{mg} / \mathrm{L}]$} & 284 & 635 & & 123.6 \\
\hline Iron & {$[\mathrm{mg} / \mathrm{L}]$} & 1.21 & 86.2 & & 7024.0 \\
\hline Cupper & {$[\mathrm{mg} / \mathrm{L}]$} & 0.15 & 32.9 & & 21833.3 \\
\hline Zinc & {$[\mathrm{mg} / \mathrm{L}]$} & 0.20 & 38.6 & & 19200.0 \\
\hline $\mathrm{C} / \mathrm{N}$ ratio & & & 10.5 & & \\
\hline Manganese & {$[\mathrm{mg} / \mathrm{L}]$} & 0.01 & 10.5 & & 104900.0 \\
\hline Boron & {$[\mathrm{mg} / \mathrm{L}]$} & 1.88 & 15.9 & & 745.7 \\
\hline
\end{tabular}

${ }^{1}$ based on the OLR of $1.0 \mathrm{kgVS} / \mathrm{m}^{3} \mathrm{~d}$.

Table 6. Humic and fulvic content in the effluent of the pilot-scale CSTR operation in the anaerobic treatment of turkey manure.

\begin{tabular}{lllll}
\hline $\begin{array}{l}\text { OLR } \\
{\left[\mathrm{kgVS} / \mathrm{m}^{3} \mathrm{~d}\right]}\end{array}$ & $\begin{array}{l}\text { Effluent } \\
\text { fraction }\end{array}$ & $\begin{array}{l}\text { Fulvic } \\
\text { acids } \\
{[\mathrm{g} / \mathrm{L}]}\end{array}$ & $\begin{array}{l}\text { Humic } \\
\text { acids } \\
{[\mathrm{g} / \mathrm{L}]}\end{array}$ & $\begin{array}{c}\text { Fulvic and } \\
\text { humic } \\
\text { acids }[\mathrm{g} / \mathrm{L}]\end{array}$ \\
\hline 1.5 & $\begin{array}{l}\text { Liquid } \\
\text { fraction of } \\
\text { the effluent }\end{array}$ & 0.04 & 2.32 & 2.36 \\
& $\begin{array}{l}\text { Entire } \\
\text { effluent }\end{array}$ & 0.60 & 2.04 & 2.64 \\
\hline
\end{tabular}

\section{Conclusions}

It is possible to achieve the anaerobic mono-digestion of turkey manure, without its codigestion. The anaerobic mono-digestion is an appropriate alternative to convert the turkey manure to methane and obtain a stable waste with characteristic (according to the nutrient and humic and fulvic acids content) that can be applied as soil conditioner or fertilizer, based on the performance of a mesophilic pilot-scale continuous stirred tank reactor. In this way, the application of the anaerobic digestion allows a process without pollutant emissions, obtaining two products. The anaerobic digestion of turkey manure and, therefore, the methane and fertilizer/soil conditioner production depend on the organic load rate. The reactor operation does not allow an OLR above $1.5 \mathrm{kgVS} / \mathrm{m}^{3} \mathrm{~d}$.

\section{Acknowledgements}

This research was supported by Pontificia Universidad Católica de Valparaíso.

\section{References}

[1] I. Angelidaki, L. Ellegaard and B. Ahring, "Applications of the Anaerobic Digestion Process," In: T. Scheper, Ed., Advances in Biochemical Engineering/Biotechnology 82, Springer-Verlag, Berlin Heidelberg, 2003, pp. 1-33.

[2] W. Edelmann, "Products, Impacts and Economy of Anaerobic Digestion of OFMSW," In: J. Mata-Alvarez, Ed., Biomethanization of the Organic Fraction Of Municipal Solid Wastes, IWA Publishing, London, 2003, pp. 265-301.

[3] P. Vandevivere, L. De Baere and W. Verstraete, "Types of Anaerobic Digester for Solid Waste," In: J. Mata-Alvarez, Ed., Biomethanization of the Organic Fraction Of Municipal Solid Wastes, IWA Publishing, London, pp. 111-140.

[4] A. P. H. A., "Standard Methods for the Examination of Water and Wastewaters," 20th Edition, American Public Health Association, Washington D.C., 1998.

[5] A. Sadzawka, M. A. Carrasco, R. Grez, M. L. Mora, H. Flores and A. Neaman, "Recommended Analytical Methods for the Chilean Soils," Standards and Accreditation Committee, Chilean Society of Soil Science, Santiago (in Spanish), 2006.

[6] D. S. Orlov and L. A. Grishina, "Practical Manual of Humus Chemistry," Moscow University Press, Moscow (in Russian), 1981.

[7] J. Field, R. Sierra Álvarez and G. Lettinga, "Ensayos Anaerobios", Actas del 4 Seminario D. A. A. R.: Depuración Anaerobia de Aguas Residuales, Valladolid, 1988, pp. 52-81.

[8] T. Espinosa-Solares, J. Bombardiere, M. Chatfield, M. Domaschko, M. Easter, D. A. Stafford, S. Castillo-Angeles and N. Castellanos-Hernandez, "Macroscopic Mass and Energy Balance of a Pilot Plant Anaerobic Bioreactor Operated under Thermophilic Conditions," Applied Biochemistry and Biotechnology, Vol. 132, No. 1-3, 2006, pp. 959-968. doi:10.1385/ABAB:132:1:959

[9] P. Kaparaju, I. Buendia, L. Ellegaard and I. Angelidakia, "Effects of Mixing on Methane Production during Thermophilic Anaerobic Digestion of Manure: Lab-Scale and Pilot-Scale Studies," Bioresource Technology, Vol. 99, No. 11, 2008, pp. 4919-4928. 
doi:10.1016/j.biortech.2007.09.015

[10] L. M. Safley, R. L. Vetter and D. Smith, "Operating a Full-Scale Poultry Manure Anaerobic Digester," Biological Wastes, Vol. 19, No. 2, 1987, pp. 79-90. doi:10.1016/0269-7483(87)90102-9

[11] I. Angelidaki, X. Chen, J. Cui, P. Kaparaju and L. Ellegaard, "Thermophilic Anaerobic Digestion of SourceSorted Organic Fraction of Household Municipal Solid Waste: Start-Up Procedure for Continuously Stirred Tank Reactor," Water Research, Vol. 40, No. 14, 2006, pp. 2621-2628. doi:10.1016/j.watres.2006.05.015

[12] R. Chamy, P. Poirrier, M. C. Schiappacasse, D. Alkalay and L. Guerrero, "Effect of Ammonia Content in the Biodegradability of the Salmon Industry Waste," Bioprocess Engineering, Vol. 19, No. 1, 1998, pp. 1-5.

[13] R. Chamy, C. León, E. Vivanco, P. Poirrier and C. Ramos, "Anaerobic Monodigestion of Poultry Manure, Effective Alternative against Codigestion: Determination of Operation Parameters for CSTR," Proceedings of the 12th World Congress on Anaerobic Digestion, Guadalajara, Mexico, 2010.

[14] I. Angelidaki and B. K. Ahring, "Anaerobic Thermophilic Digestion of Manure at Different Ammonia Loads: Effects of Temperature," Water Research, Vol. 28, No. 3, 1994, pp. 727-731. doi:10.1016/0043-1354(94)90153-8

[15] I. Angelidaki and B. K. Ahring, "Thermophilic Anaerobic Digestion of Livestock Waste: The Effect of Ammonia," Applied Biochemistry and Biotechnology, Vol. 38, 1993, pp. 560-564.

[16] L. A. De Baere, M. Devocht, P. Van Assche and W. Verstraete, "Influence of high $\mathrm{NaCl}$ and $\mathrm{NH}_{4} \mathrm{Cl}$ salt levels on methanogenic associations", Water Research, Vol. 18, No. 5, 1984, pp. 543-548. doi:10.1016/0043-1354(84)90201-X

[17] N. Krylova, R. E. Khabiboulline, R. P Naumava and M. A. Nagel, "The Influence of Ammonium and Methods for Removal during the Anaerobic Treatment of Poultry Manure," Journal of Chemical Technology \& Biotechnology Vol. 70, No. 1, 1997, pp. 99-105.

[18] T. Liu and S. Sung, "Ammonia Inhibition on Thermophilic Aceticlastic Methanogens," Water Science and Technology, Vol. 45, No. 10, 2002, pp. 113-120.

[19] F. Omil, R. Méndez and J. M. Lema, "Anaerobic Treat- ment of Saline Wastewaters under High Sulphide and Ammonia Content," Bioresource Technology, Vol. 54, 1995 , pp. $269-278$. doi:10.1016/0960-8524(95)00143-3

[20] S. Sung and T. Liu, "Ammonia Inhibition on Thermophilic Anaerobic Digestion," Chemosphere, Vol. 53, No. 1, 2003, pp. 43-52. doi:10.1016/S0045-6535(03)00434-X

[21] A. F. M. van Velsen, "Adaptation of Methanogenic Sludge to High Ammonia-Nitrogen Concentrations," Water Research, Vol. 13, 1979, pp. 995-999. doi:10.1016/0043-1354(79)90194-5

[22] G. N. Demirer and S. Chen, "Two-Phase Anaerobic Digestion of Unscreened Dairy Manure," Process Biochemistry, Vol. 40, No. 11, 2005, pp. 3542-3549. doi:10.1016/j.procbio.2005.03.062

[23] J. Gelegenis, D. Georgakakis, I. Angelidaki, N. Christopoulou and M. Goumenaki, "Optimization of Biogas Production from Olive.Oil Mill Wastewater, by Codigesting with Diluted Poultry-Manure," Applied Energy, Vol. 84, No. 6, 2007, pp. 646-663. doi:10.1016/j.apenergy.2006.12.001

[24] K. Karim, R. Hoffmann, K. T. Klasson and M. H. Al-Dahhan, "Anaerobic Digestion of Animal Waste: Effect of Mode of Mixing," Water Research, Vol. 39, No. 15, 2005, pp. 3597-3606. doi:10.1016/j.watres.2005.06.019

[25] K. Karim, R. Hoffmann, T. Klasson and M. H. Al-Dahhan, "Anaerobic Digestion of Animal Waste: Waste Strength versus Impact of Mixing," Bioresource Technology, Vol. 96, No. 16, 2005, pp. 1771-1781. doi:10.1016/j.biortech.2005.01.020

[26] A. Lehtomäki, S. Huttunen and J. A. Rintala, "Laboratory Investigations on Co-Digestion of Energy Crops and Crop Residues with Cow Manure for Methane Production: Effect of Crop to Manure Ratio," Resources, Conservation and Recycling, Vol. 51, No. 3, 2007, pp. 591-609. doi:10.1016/j.resconrec.2006.11.004

[27] Z. Pechan, O. Knappová, B. Petrovičová and O. Adamec, "Anaerobic Digestion of Poultry Manure at High Ammonium Nitrogen Concentrations," Biological Wastes, Vol. 20, No. 2, 1987, pp. 117-131. doi:10.1016/0269-7483(87)90162-5 